\title{
Respon kecemasan orang tua terhadap hospitalisasi anak Di RSUP Dr. M.Djamil Padang
}

\author{
Hermalinda $^{a}$, Deswita ${ }^{a}$, Rika Sarfika ${ }^{b}$ \\ aBagian Keperawatan Maternitas dan Anak, Fakultas Keperawatan Universitas, Padang, \\ 25163, Indonesia

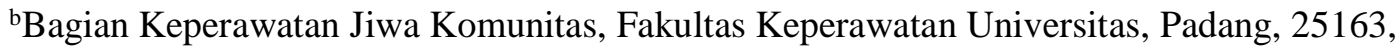 \\ Indonesia \\ e-mail korespondensi: hermalinda.nrs.unand.ac.id
}

\begin{abstract}
Hospitalization is a stressful experience for both children and their family. This will influence the effectiveness of treatment that is conducted on children and has an impact on the healing process of children. This research aimed to identify the anxiety responses of parents over the hospitalization of children. The design was descriptive analytic with cross-sectional study approach. This research was carried out in pediatrics wards of DR. M.Djamil Hospital from June to October 2018. A total of 133 parents/caregivers participated in this research. Data were collected using the Short STAI (State-Trait Anxiety Inventory) questionnaire and a questionnaire about factors that related to parents' anxiety. Data were analyzed by using the Kruskal Wallis and Mann Whitney test. The results showed that the parents' anxiety score was 18.02 with a standard deviation of 3.69., the lowest score was 7 and the highest was 24. There was a relationship between the duration of stay, previous treatment experience, and condition of children with parents' anxiety. It is expected that nurses can identify stress or parents anxiety by conducting a comprehensive assessment.
\end{abstract}

Keywords: Anxiety, hospitalization, and parent anxiety

\begin{abstract}
Abstrak
spitalisasi merupakan pengalaman penuh stres baik bagi anak maupun keluarganya. Hal ini akan mempengaruhi keefektifan dari pengobatan yang dilakukan pada anak dan berdampak terhadap proses penyembuhan anak. Penelitian ini bertujuan untuk mengidentifikasi respon kecemasan orang tua terhadap hospitalisasi anak. Desain penelitian adalah deskriptif analitik dengan pendekatan cross-sectional study. Penelitian ini dilakukan di Ruang perawatan anak RSUP DR. M.Djamil mulai dari bulan Juni sampai dengan bulan Oktober 2018. Sebanyak 133 orang tua/care giver berpartisipasi dalam penelitian ini. Data dikumpulkan dengan menggunakan kuesioner Short STAI (State-Trait Anxiety Inventory) dan kuesioner tentang faktor yang berhubungan dengan kecemasan orang tua. Data dianalisis dengan menggunakan uji kruskal wallis dan mann-whitney U. Hasil penelitian menunjukkan bahwa skor kecemasan orang tua adalah 18.02 dengan standar deviasi 3.69, skor terendah 7 dan skor tertinggi 24. Terdapat hubungan antara lama dirawat, pengalaman dirawat sebelumnya, dan kondisi anak dengan kecemasan orang tua. Diharapkan perawat dapat mengidentifikasi stress atau kecemasan pada orang tua dengan melakukan pengkajian yang komprehensif.
\end{abstract}

Kata kunci: Hospitalisasi, Kecemasan, dan kecemasan orang tua

\section{PENDAHULUAN}

Hospitalisasi

pada anak

menyebabkan stress dan kecemasan pada orangtua terutama ibu. Stress tersebut akan memberikan dampak terhadap pengobatan dan proses penyembuhan anak (Tayebeh Tehrani, 2012; Commodari, 2010). Stres maternal dan kemasan dapat juga berdampak terhadap anak melalui dua cara Hermalinda, dkk., Respon kecemasan orang tua .... yaitu pemindahan stres kepada anak dan ketidakmampuan dalam merawat anak (Tayebeh Tehrani, 2012).

Pengalaman terhadap hospitalisasi anak dapat dianggap sebagai proses untuk mengembalikan kesehatan. Perawat dapat memudahkan proses ini dengan menunjukan pentingnya pengalaman dan perasaan individu pada waktu hospitalisasi 
dan membantu mereka beradaptasi terhadap lingkungan (Bsiri-Moghaddam et al., 2011).

Selain itu diperlukan pendidikan kepada orang tua tentang perawatan dan proses pengobatan, mengajarkan tentang perawatan di rumah, melibatkan orang tua dalam proses perawatan dan melibatkan partisipasi dalam membuat keputusan (klarifikasi peranan orang tua) yang bertujuan untuk meningkatkan kualitas perawatan yang diberikan kepada anak (Vasli \& Salsali, 2014).

Paradigma terbaru tentang
pelayanan perawatan pada anak merekomendasikan kehadiran orang tua di rumah sakit, partisipasi dalam perawatan dan keterlibatan dalam proses kehidupan anak, memperkuat pola asuh dan memberikan kekuatan pada orang tua. Orang tua membutuhkan, menilai semua aspek yang berhubungan dengan kondisi kesehatan anak dan mengetahui implikasi penyakit pada masa depan. Penting bagi tenaga profesional perawatan untuk menyesuaikan perubahan dan pengetahuan terbaru tersebut dan melaksanakannya dalam praktek untuk mendorong keterlibatan dan partisipasi dari orang tua dalam perawatan anak sesuai dengan kebutuhan anak dan keluarga, sharing informasi, mempromosikan kesehatan dan berkontribusi terhadap kualitas pelayanan perawatan (de Melo et al, 2014).

Suatu studi mengkonfirmasikan bahwa pada umumnya anak dan remaja yang dirawat sering berfikir tentang rumah mereka, orang tua, sekolah dan teman. Lebih dari sebagian anak dan remaja mengungkapkan bahwa informasi dan anjuran lebih banyak mereka dapatkan dari staf medis (Cmkovic et al, 2009) .

Beberapa tema yang diidentifikasi dari pengalaman anak dan orang tua selama hospitalisasi adalah penyakit, lingkungan rumah sakit, hubungan timbal balik, masalah personal orang tua, masalah mental dan emosional, serta dimensi spritual (Bsiri-Moghaddam, Basiri-
Moghaddam, Sadeghmoghaddam, \& Ahmadi, 2011).

Penyakit dan dirawat dapat merubah kebiasaan rutin anak dan keluarga karena pengalaman tersebut merupakan situasi yang kritis dan rumit untuk seluruh keluarga dan menjadi sumber penderitaan bagi keluarga. Rumah sakit terkadang dipandang sebagai tempat yang menakutkan karena lingkungan rumah sakit yang tidak mencirikan kekhasan anak. Sehingga penderitaan anak ditentukan oleh konteks pengalaman dan oleh dukungan atau interaksi pengalaman mereka. Fakta ini dapat mempengarhi respon mereka terhadap hospitalisasi dan merefleksikan konsekuensi terhadap perkembangan anak (Gomes et al, 2015).

Faktor-faktor yang menyebabkan stres atau kecemasan pada orang tua ketika anak di rumah sakit adalah ; (1) faktor anak; ketakutan terhadap kematian anak, faktor sosioekonomi, takut penyakit pada anak yang lain, (2) faktor lingkungan; ruangan yang tidak menyenangkan, (3) faktor tenaga kesehatan; tidak cukup penjelasan tentang pemasangan jalur intravena (Tehrani, Haghighi., \& Bazmaoun, 2012).

Menurut penelitian yang dilakukan oleh Commodari tahun 2010 di Itali, faktor yang mempengaruhi stress dan kecemasan orang tua terhadap hospitalisasi anak adalah penyakit anak, lama hari rawatan, pelibatan dalam aktivitas perawatan anak serta pelayanan sekolah.

Penelitian lain menyatakan bahwa tidak ada hubungan yang bermakna antara kecemasan anak dengan sifat kecemasan orang tua, usia anak, pendidikan dan pekerjaan orang tua dan tingkat kecemasan (Nabavi, Shoja, Ramezani, Saki, \& Joodi, 2017).

Sedangkan di Indonesia, tidak banyak penelitian yang membahas tentang kecemasan orang tua akibat hospitalisasi anak. Sehingga penelitian ini perlu dilakukan. 


\section{METODE}

\section{Desain penelitian}

Jenis penelitian ini adalah deskriptif analitik dengan menggunakan pendekatan cross-sectional study. Penelitian ini bertujuan untuk mengidentifikasi respon kecemasan orang tua terhadap hospitalisasi anak.

\section{Populasi dan sampel}

Populasi pada penelitian ini orang tua dengan anak yang menjalani hospitalisasi di ruang perawatan anak RSUP DR. M.Djamil Padang. Teknik pengambilan sampel yang digunakan dalam penelitian ini adalah accidental sampling dengan jumlah sampel yaitu 133 orang tua/care giver, dengan kriteria inklusi : bersedia menjadi responden, dapat membaca dan menulis dengan baik serta orang tua/caregiver yang menemani anak di rumah sakit.

\section{Alat pengumpulan data}

Instrumen penelitian ini adalah kuesioner. Kuesioner yang digunakan terdiri atas pertanyaan tentang identitas orang tua (usia, tingkat pendidikan, pekerjaan, status sosial ekonomi), identitas anak (usia, jenis kelamin, dan lama dirawat) serta kecemasan orang tua. Alat ukur kecemasan orang tua menggunakan short STAI (Statetrait anxiety inventory) (Tluczek et al, 2009). Kuesioner ini terdiri dari 6 pernyataan dengan rentang skor 6 sampai 24, dimana skor 6 menunjukkan tidak ada kecemasan dan 24 menyatakan kecemasan yang berat/ tinggi. Kuesioner ini telah dilakukan uji validitas dan reablitas, uji validitas dengan internal konsistens reliabilitis lebih dari 90.

\section{Prosedur pengumpulan data}

1. Persiapan

Pada tahap persiapan peneliti melakukan beberapa kegiatan seperti mengurus perizinan, pemilihan sampel, dan informed consent kepada orang tua.
Sebelum penelitian dilakukan, peneliti telah mendapatkan persetujuan etik dari komite etik kesehatan RSUP DR. M.Djamil Padang.

2. Penelitian

Orang tua yang telah menyetujui untuk berpartisipasi dalam penelitian ini kemudian diberikan kuesioner dan didampingi oleh peneliti dalam pengisian kuesioner. Waktu yang dibutuhkan dalam mengisi kuesioner adalah 30-45 menit.

3. Terminasi

Peneliti mengucapkan terimakasih kepada orang tua yang telah berpartisipasi dalam penelitian ini.

\section{Analisis data}

Data dianalisis secara univariat untuk melihat sebaran data dan distribusi frekuensi dari variabel yang diteliti. Untuk analisis bivariat, karena data tidak berdistribusi normal, maka data dianalisis dengan menggunakan uji kruskal wallis dan mann whitney.

\section{HASIL}

\section{Gambaran skor kecemasan orang tua}

Tabel 1. Skor Kecemasan orang tua di RSUP M.Djamil Padang

\begin{tabular}{llll}
\hline Variable & Mean & SD & Min - max \\
\hline $\begin{array}{l}\text { Skor } \\
\text { kecemasan } \\
\text { orang tua }\end{array}$ & 18.02 & 3.69 & $7-24$ \\
\hline
\end{tabular}

Pada tabel 1 diatas, dapat dilihat bahwa rata-rata skor kecemasan orang tua adalah 18.02 dengan standar deviasi 3.69. Nilai skor kecemasan terendah adalah 7 dan tertinggi 24.

\section{Kecemasan berdasarkan karakteristik responden}


Tabel 2. Kecemasan orangtua berdasarkan karakteristik responden

\begin{tabular}{|c|c|c|c|c|}
\hline $\mathbf{N}$ & Karakteristik & $\begin{array}{l}\text { Jumlah } \\
\text { (f) }\end{array}$ & $\begin{array}{l}\text { Persentase } \\
(\%)\end{array}$ & $\begin{array}{l}p \\
\text { value }\end{array}$ \\
\hline 1 & $\begin{array}{l}\text { Usia ibu } \\
<25 \text { tahun } \\
25-48 \text { tahun } \\
>48\end{array}$ & $\begin{array}{l}9 \\
114 \\
10 \text { o }\end{array}$ & $\begin{array}{l}6.8 \\
85.7 \\
7.5\end{array}$ & 0.013 \\
\hline 2 & $\begin{array}{l}\text { Pendidikan } \\
\text { ibu } \\
\text { Rendah } \\
\text { Tinggi }\end{array}$ & $\begin{array}{l}61 \\
72\end{array}$ & $\begin{array}{l}45.9 \\
54.1\end{array}$ & 0.703 \\
\hline 3 & $\begin{array}{l}\text { Pekerjaan } \\
\text { ibu } \\
\text { Tidak bekerja } \\
\text { Bekerja }\end{array}$ & $\begin{array}{l}107 \\
26\end{array}$ & $\begin{array}{l}80.5 \\
19.5\end{array}$ & 0.782 \\
\hline 4 & $\begin{array}{l}\text { Usia anak } \\
\text { Bayi } \\
\text { Todler dan } \\
\text { prasekolah } \\
\text { Sekolah } \\
\text { Remaja } \\
\end{array}$ & $\begin{array}{l}37 \\
31 \\
43 \\
22\end{array}$ & $\begin{array}{l}27.8 \\
23.3 \\
32.3 \\
16.5\end{array}$ & 0.198 \\
\hline 5 & $\begin{array}{l}\text { Lama hari } \\
\text { rawat } \\
1-4 \text { hari } \\
4-10 \text { hari } \\
>10 \text { hari }\end{array}$ & $\begin{array}{l}55 \\
41 \\
37\end{array}$ & $\begin{array}{l}41.4 \\
30.8 \\
27.8\end{array}$ & 0.304 \\
\hline 6 & $\begin{array}{l}\text { Pengalaman } \\
\text { dirawat } \\
\text { Belum pernah } \\
\text { Pernah }\end{array}$ & $\begin{array}{l}40 \\
93\end{array}$ & $\begin{array}{l}30.1 \\
69.9\end{array}$ & 0.079 \\
\hline
\end{tabular}

Pada Tabel 2. dapat dilihat bahwa hampir sebagian besar responden berusia 25-48 tahun $(85,7 \%)$ dan lebih dari sebagian ibu memiliki pendidikan yang tinggi $(54,1 \%)$. Responden dalam penelitian ini hampir sebagian besar bekerja sebagai ibu rumah tangga $(80.5 \%)$. Usia anak dari responden paling banyak adalah pada usia sekolah yaitu sebesar $32.3 \%$. Hampir sebagian anak dirawat selama 4-10 hari yaitu sebesar $30.8 \%$. Sekitar $69.9 \%$ responden mempunyai pengalaman anak di rawat di rumah sakit. Analisis lebih lanjut menunjukkan adanya perbedaan kecemasan ibu berdasarkan usia ibu namun tidak terdapat perbedaan kecemasan ibu berdasarkan faktor pendidikan ibu,

Hermalinda, dkk., Respon kecemasan orang tua .... pekerjaan ibu, usia anak, lama hari rawatan dan pengalaman dirawat sebelumnya.

\section{PEMBAHASAN}

Pada penelitian ini dapat dilihat bahwa hospitalisasi memberikan dampak psikologis terhadap orangtua atau caregiver. Respon tersebut adalah kecemasan dengan rentang yang cukup tinggi (mean skor 18.02). Penelitian sebelumnya mengidentifikasi tentang kecemasan orang tua terkait dengan perawatan anak dengan rata-rata skor kecemasan orang tua adalah $2.87 \pm 0.69$ (Palma et al, 2017). Perbedaan skor kecemasan orang tua ini disebabkan karena alat pengukuran kecemasan yang berbeda.

Keluarga merupakan sistem dalam interaksi antara satu orang dengan orang lain. Interaksi tersebut dipengaruhi oleh sistem keluarga dan lingkungan. Perubahan pada bagian dalam sistem seperti anak sakit akan mempengaruhi interaksi didalam sistem (Glesper \& Richardson, 2006). Penyakit dan hospitalisasi pada anak merupakan krisis dan dapat memberikan efek pada semua anggota keluarga (Glesper \& Richardson, 2006; Hockenberry \& Wilson, 2013). Penyakit pada anak akan memberikan efek umum bagaimana cara orang tua mengatasi masalah seperti distress, marah, menolak dan melepaskan peran pengasuhan normal. Anak dapat merasa diabaikan oleh orang tua mereka dan kehilangan rasa percaya terhadap keputusan yang telah diambil orang tua (Glesper \& Richardson, 2006).

Beberapa respon orang tua terhadap horpitalisasi anak diantaranya adalah rasa tidak berdaya, mempertanyakan tentang kemampuan tenaga kesehatan, menerima kenyataan anak harus dirawat, membutuhkan informasi dengan bahasa yang sederhana, menghadapi rasa takut, mengatasi ketidakpastian, dan mencari sumber daya untuk pengasuhan anak (Hockenberry \& Wilson, 2013).

Pada penelitian ini kecemasan yang dialami oleh orangtua berbeda berdasarkan 
usia. Skor kecemasan lebih tinggi pada orang tua dengan usia dewasa muda (usia kurang dari 25 tahun). Hasil penelitian ini didukung oleh penelitian sebelumnya. Tidak ada perbedaan tingkat stress orang tua antara ayah dan ibu terhadap perawatan bayi mereka di rumah sakit dan tidak ada hubungan tingkat stress orang tua dengan kondisi klinis bayi mereka (Palma et al, 2017)

Hasil penelitian menunjukkan tidak ada perbedaan antara skor kecemasan ibu berdasarkan pendidikan ibu, pekerjaan ibu, usia anak, lama hari rawatan dan pengalaman dirawat sebelumnya.

Hasil yang berbeda dapat dilihat pada penelitian yang dilakukan oleh Tehrani, Haghighi., \& Bazmaoun tahun 2012 yang membuktikan bahwa Terdapat hubungan yang signifikan antara stress dengan usia dan pekerjaan ibu, usia anak, hari rawatan, cara masuk dan penggunaan asuransi kesehatan. Hasil penelitian yang sama juga menyatakan bahwa persepsi stres dipengaruhi oleh lama hari rawatan dan tingkatan keluarga (Commodari, 2010).

Reaksi orang tua terhadap penyakit anak tergantung terhadap beberapa faktor. Walaupun faktor tersebut tidak secara langsung mempengaruhi respon orang tua, namun beberapa faktor teridentifikasi seperti keseriusan penyakit anak, pengalaman sebelumnya terhadap hospitalisasi, prosedur pengobatan termasuk pemeriksaan diagnostik dan pengobatan, tersedianya sumber dukungan, kekuatan ego personal, kemampuan koping, adanya stress dalam keluaga, budaya, agama dan kepercayaan serta pola komunikasi dalam keluarga (Hockenberry \& Wilson, 2013) .

Masalah yang dialami orang tua ketika anak dirawat diantaranya adalah perubahan gaya hidup, masalah finansial, kondisi pekerjaan, perubahan dan kondisi anggota keluarga lainnya. Perubahan gaya hidup seperti perubahan tempat istirahat, dan lingkungan fisik yang meliputi tempat untuk duduk, suara bising di rumah sakit yang berasal dari anak lain yang dirawat atau dari tenaga rumah sakit. Selain itu perubahan gaya hidup yang dirasakan orang tua adalah perubahan jadwal bekerja dan rutinitas seperti mandi, tidur dan terbangun (Bsiri-Moghaddam, BasiriMoghaddam, Sadeghmoghaddam, \& Ahmadi, 2011).

Sumber stress kecemasan orang tua yang dapat dilihat pada penelitian ini adalah berasal dari faktor anak. Orang tua memiliki kecemasan yang sangat tinggi apabila memikirkan tentang kemungkinan penyakit anak menjadi parah dan khawatir anak akan meninggal. Orang tua juga cemas dengan kondisi anak seperti anak menjadi lemah, letih dan lesu, nyeri yang dirasakan anak serta adany perubahan perilaku pada anak setelah sakit. Tidak banya orang tua yang cemas terhadap pengobatan yang dijalani anak seperti pemasangan infus karena hal tersebut merupakan tindakan yang dapat membantu meningkatkan kesembuhan anak.

Penelitian dilakuan pada 225 anak yang dirawat di rumah sakit Besat hospital, Hamedan. Hasil penelitian menunjukkan bahwa faktor anak diantaranya takut akan kematian anak sebesar $84 \%$, faktor sosial ekonomi; takut penyakit pada anak yang lain $84 \%$ dan faktor lingkungan ; lingkungan ruangan yang tidak menyenangkan sebesar 56\%, untuk kategori tenaga kesehatan, tidak cukup penjelasan tentang tindakan insersi jalur intravena $54,2 \%$ yang merupakan faktor yang paling penting (Tehrani, Haghighi., \& Bazmaoun, 2012).

Stressor yang paling umum menyebabkan kecemasan pada orang tua adalah melihat anak sakit dan hanya sebagian kecil orang tua yang merasa cemas tentang peralatan medis (Elmaelzadeh, 2003). Melihat anak merasakan nyeri adalah hal yang sulit untuk orang tua. Hal ini terasa lebih berat karena anak dalam kondisi darurat, pengobatan yang lama, kondisi penyakit 
kronik, prognosis yang kurang baik, kurangnya dukungan keluarga dan kurangnya finansial atau layanan komunitas (Ball \& Bindler, 2010).

Banyak orang tua yang merasakan baik perasaan lega maupun rasa bersalah ketika anak dirawat. Perasaan lega karena merasa yakin bahwa anak mereka akan di rawat oleh orang yang memiiki ketrampilan dan sumber daya untuk melakukan sesuatu secara efektif. Rasa bersalah karena mereka cemas apabila perawatan yang diberikan tidak tepat dan tidak sesuai dengan apa yang mereka harapkan. Orang tua juga merasa kecewa atau marah karena layanan kesehatan yang telah mereka cari membuat mereka yakin bahwa anak mereka tidak sakit seperti yang mereka takutkan (Glesper \& Richardson, 2006).

\section{KESIMPULAN DAN SARAN}

Kecemasan pada orang tua pada penelitian ini cukup tinggi yang berkaitan dengan kondisi anak, perubahan sikap anak setelah sakit, penyakit anak menjadi serius dan khawatir anak meninggal. Kecemasan orang tua lebih tinggi pada orang tua dewasa muda. Namun tidak ada perbedaan kecemasan orang tua berdasarkan pendidikan ibu, pekerjaan ibu, usia anak, lama hari rawatan dan pengalaman sebelumnya. Diharapkan perawat dapat mengidentifikasi stress atau kecemasan pada orang tua dengan melakukan pengkajian yang komprehensif.

\section{UCAPAN TERIMA KASIH}

Peneliti mengucapkan terimakasih kepada Fakultas Keperawatan Universitas Andalas yang telah memberikan suport dan dukungan dana dalam penelitian ini. Peneliti juga mengucapkan terimakasih kepada seluruh responden yang telah berpartisipasi dalam penelitian ini.

\section{DAFTAR PUSTAKA}

Ball, J. W, and Bindler, R. C., (2010). Pediatric of nursing: caring for children. Pearson Education, Inc: New Jersey, America

Bsiri-Moghaddam, K., Basiri-Moghaddam, M., Sadeghmoghaddam, L., \& Ahmadi, F. (2011). The concept of hospitalization of children from the view point of parents and children. Iranian Journal of Pediatrics, 21(2), 201-208. https://doi.org/10.1186/1471-243114-276

Cao, X., Yumul, R., Lazo, O. L. E., Friedman, J., Durra, O., Zhang, X., \& White, P. F. (2017). A novel visual facial anxiety scale for assessing preoperative anxiety. PLOS ONE, 12(2), 1-7. https://doi.org/10.1371/journal.pone.0 171233

Commodari, E. (2010). Children staying in hospital: a research on psychological stress of caregivers. Italian Journal of Pediatrics, $36, \quad 40$. https://doi.org/10.1186/1824-728836-40

Crnkovic, M., Divcic, B., Rotim, Z., \& Coric, J. (2009). Emotions and experiences of hospitalized school age patients. Acta Clinica Croatica, 48, 125-135.

Esmaelzadeh. (2003). Stressors of mother of hospitalized neonates in Qod hospital. Jurnal of Qazvin University Medical Science, 6 (4); 40-5

Glasper, E.A., \& Richardson, J. (2006). A Textbook of children's and young people's nursing. Toronto: Churchill Livingstone Elsevier

Gomes, G. L. L., \& Nóbrega, M. M. L. da. (2015). Anxiety in children following hospitalization: a proposal for a nursing diagnosis. Revista LatinoAmericana de Enfermagem, 23(5), 963-970.

https://doi.org/10.1590/01041169.0372 .2637

Hockenberry, M. J. (2013). Wong's Essentials of Pediatric Nursing (9 th Ed). St. Louis: Mosby Elsevier. 
Koukourikos, K., Tzeha, L., Pantelidou, P., \& Tsaloglidou, A. (2015). The Importance of Play During Hospitalization of Children. Materia Socio Medica, 27(6), 438. https://doi.org/10.5455/msm.2015.27. 438-441

Kyle, T. (2013). Pediatric Nursing Clinical Guide. China: Lippincoat Williams \& Wilkins.

Li, W. H. C., Chung, J. O. K., Ho, K. Y., \& Kwok, B. M. C. (2016). Play interventions to reduce anxiety and negative emotions in hospitalized children. BMC Pediatrics, 16(1), 36. https://doi.org/10.1186/s12887-0160570-5

Moura, L. A. de, Dias, I. M. G., \& Pereira, L. V. (2016). Prevalence and factors associated with preoperative anxiety in children aged 5-12 years. Revista Latino-Americana de Enfermagem, 24(0). https://doi.org/10.1590/15188345.0723.2708

Muscari, M. E. (2010). Advances pediatrir clinical assessment: skill and procedure. Philadelphi: Lippincoat.

Nabavi, F. H., Shoja, M., Ramezani, M., Saki, A., \& Joodi, M. (2017). Investigating the Relationship between Anxiety of School-age Children Undergoing Surgery and Parental State-trait Anxiety, (098 51). https://doi.org/10.22038/EBCJ.2017.2 0999.1481

Nilsson, S., Buchholz, M., \& Thunberg, G. (2012). Assessing Children's Anxiety Using the Modified Short State-Trait Anxiety Inventory and Talking Mats: A Pilot Study. Nursing Research and Practice, 2012, 1-7. https://doi.org/10.1155/2012/932570

Ortigosa Quiles, J. M., García-Banda García, G., Chellew, K., Ponsell Vicens, E., Riquelme Marín, A., \& Nicolás Carrasco, M. P. (2013). Identificación de grados de ansiedad en niños con escalas faciales de tres y cinco caras. Psicothema, 25(4), 446-
451.

https://doi.org/10.7334/psicothema20 $\underline{12.287 .}$

Palma, E. I. et al. (2017). Stress in parents od newborns hospitalized in a Neonatal Intensive Care Unit. Review of Children Pediatric, 88 (3); 332-339.

Saharan, P. (2017). Assess the Effectiveness of Play Interventions on Anxiety among Hospitalized Children in Selected Hospital of Yamuna Nagar , Haryana: An Experimental Study, 2(11), 88-94.

Tayebeh Tehrani, M. H. and H. B. (2012). Effects of Stress on Mothers of Hospitalized Children in a Hospital in Iran. National Center for Biotechnology Information, 6(4), 3949. Retrieved from Effects of Stress on Mothers of Hospitalized Children in a Hospital in Iran

Vasli, P., \& Salsali, M. (2014). Parents' participation in taking care of hospitalized children: A concept analysis with hybrid model. Iranian Journal of Nursing \& Midwifery Research, 19(2), 139144. Retrieved from http://search.ebscohost.com/login. aspx?direct $=$ true $\& d b=a 9 h \& A N=9$ $5849153 \&$ site $=$ ehost-live 